\title{
ANALISIS HUBUNGAN PENGGUNAAN MEDIA SOSIAL DENGAN KUALITAS TIDUR PADA REMAJA
}

\author{
Kezia Woran ${ }^{1}$, Rina M. Kundre ${ }^{2}$, Ferlan A. Pondaag ${ }^{3}$ \\ ${ }^{1}$ Mahasiswa Program Studi Ilmu Keperawatan, Fakultas Kedokteran, Univeristas Sam \\ Ratulangi, Indonesia \\ ${ }^{2,3}$ Program Studi Ilmu Keperawatan Fakultas Kedokteran Universitas Sam Ratulangi \\ Email : Kezia.worann@gmail.com
}

\begin{abstract}
Social media is an online platform through internet-based applications and most of the users are Adolescents. Adolescent habits of spending a long time using social media caused disruption of rest and sleep patterns resulting poor quality of sleepr. The purpose of this study was to determine the relationship between the usage of social media and sleep quality of Adolescents in grade XI Mathematics and Sciences State Senior High School 1 Langowan. This study used descriptive analytic with Cross Sectional Study approach. The sampling technique used purposive sampling with a total sample of 80 Adolescents. The Result of statistical test studies using the Fisher Exact test and obtained a significant value $\rho=0,000<\alpha=0.05$. This study concluded there was a relationship between the use of social media and sleep quality in adolescents in class XI Mathematics and Sciences State Senior High School 1 Langowan. This study recommend that adolescents will be able to reduce the use of social media and be able to manage the rest and sleep patterns, for schools and parents to continue watching and educating adolescents in using social media.
\end{abstract}

Key Words : Social Media, Sleep Quality, Adolescents

\begin{abstract}
Abstrak: Media sosial merupakan sebuah media online melalui aplikasi berbasis internet dan untuk pengguna terbanyak adalah remaja. Kebiasaan remaja menghabiskan waktu yang cukup lama untuk menggunakan media sosial mengakibatkan terganggunya pola istirahat dan tidur sehingga kualitas tidur menjadi buruk. Tujuan untuk mengetahui hubungan Penggunaan media sosial dengan Kualitas tidur pada remaja di kelas XI Matematika Ilmu Alam (MIA) SMA N 1 Langowan. Desain Penelitian yang digunakan yaitu Deskriptif Analitik dengan pendekatan Cross Sectional Study. Teknik pengambilan sampel menggunakan Purposive Sampling dengan jumlah sampel sebanyak 80 remaja. Hasil Penelitian uji statistik menggunakan uji Fisher Exact dan didapatkan nilai signifikan $\rho$ Value $=0,000<\alpha=0,05$. Kesimpulan terdapat hubungan antara penggunaan media sosial dan kualitas tidur pada remaja dikelas XI Matematika Ilmu Alam (MIA) SMA N 1 Langowan. Saran diharapkan remaja mampu mengurangi penggunaan media sosial dan mampu memenejemen pola istirahat dan tidur, bagi pihak sekolah dan orang tua agar tetap mengawasi dan mengedukasi remaja dalam menggunakan media sosial.
\end{abstract}

Kata Kunci : Media Sosial, Kualitas Tidur, Remaja 


\section{PENDAHULUAN}

Indonesia adalah salah satu negara yang menggunakan internet untuk berbagai macam hal, dan diIndonesia juga internet menjadi salah satu kemajuan teknologi yang sangat diminati. Internet mampu membuat manusia mengalami ketergantungan dengan kemajuan teknologi informasi ini. Hal yang sangat erat kaitannya dengan internet adalah media sosial dimana semua orang dapat berinteraksi tanpa bertemu secara langsung. Bukan hanya berinteraksi media sosial pun dapat menjadi media untuk menjalankan bisnis jual beli, saling bertukar gambar, mengirim suara bahkan bertukar informasi. Media sosial juga dapat menjadi sarana untuk hiburan, dan pada saat ini pengguna media sosial menguasai semua kalangan mulai dari anak-anak, remaja, dewasa, orang tua kini tidak asing lagi dalam menggunakan media sosial (Sudiyatmoko, 2015).

Perkembangan media sosial diIndonesia mencapai total 150 juta pengguna, ini berarti mayoritas penggunaan internet bersosialisasi melalui media sosial. Jumlah pengguna media sosial ini mencapai $56 \%$ dari jumlah total penduduk Indonesia, dengan pengguna berbasis mobilenya mencapai 130 juta (Websindo, 2019).

Menurut penetrasi pengguna internet dari jumlah penduduk untuk Sulawesi utara ada $70 \%$ penduduknya yang terkoneksi internet dan hanya $30 \%$ yang belum terjangkau akses internet. Penetrasi pengguna internet berdasarkan kategori usia mempunyai presentase setiap usia yaitu diberikan $100 \%$ dan dibagi dua yaitu pengguna internet dan bukan pengguna internet, dan untuk usia 15-19 tahun $91 \%$ pengguna internet dan $9 \%$ bukan pengguna internet, dari presentase yang ada untuk umur 15-19 tahun yaitu usia remaja menduduki persentase tertinggi (APJII, 2018).

Remaja dapat dikatakan memasuki tahap ketergantungan media sosial, terbukti mereka menghabiskan 54\% waktunya untuk online menggunakan media sosial (Woods \& Scoot 2016).
Dalam penelitian yang dilakukan oleh Nurniati (2018) yang berjudul " Hubungan durasi penggunaan media sosial dengan kualitas tidur pada remaja kelas VIII di SMP Muhammadiyah 1 Yogyakarta" ; sebagian besar responden adalah pengguna aktiv media sosial $(66,9 \%)$ sehingga memerlukan waktu yang lama untuk tertidur dari waktu biasanya akibat dari kecanggihan yang disediakan smartphone saat ini yang mengakibatkan remaja mengalami kualitas tidur yang buruk dengan presentase $(54,7 \%)$.

Remaja banyak menghabiskan waktu untuk online media sosial, termasuk pada malam hari. Hal ini juga dapat mengganggu proses tidur, sehingga kualitas serta pola tidur menjadi buruk, sebagaimana harus tidur tanpa beban pikiran. Pada faktanya, saat akan mulai tidur, mereka tetap menghiraukan pemberitahuan dari ponsel/smartphone ataupun masih berkutat dengan media sosial dalam waktu yang lama sehingga berdampak pada kualitas tidur (Woods \& Scott 2016).

Kualitas tidur adalah ukuran dimana seseorang itu dapat kemudahan dalam memulai tidur dan untuk mempertahankan tidur, kualitas tidur seseorang dapat digambarkan dengan lama waktu tidur, dan keluhan-keluhan yang dirasakan saat tidur ataupun sehabis bangun tidur. Kualitas tidur yang baik akan menghasilkan kesegaran dan kebugaran disaat terbangun, sebaliknya tidur yang tidak adekuat dan berkualitas buruk dapat mengakibatkan berbagai gangguan keseimbangan fisiologis sehingga mempengaruhi kesehatan karena waktu tidur yang cukup (minimal 7 jam dalam sehari), bila seseorang dapat tidur dalam waktu yang cukup, maka seseorang akan siap melakukan aktivitas-aktivitas yang harus dikerjakannya saat tersadar (Riyadi \& Widuri, 2015).

Penelitian yang dilakukan oleh Armaya (2017) yang berjudul "Hubungan penggunaan gadget dengan kualitas tidur pada remaja" ; berdasarkan hasil yang didapatkan bahwa dari total penggunaan 
gadget pada kategori tinggi memiliki kualitas tidur yang buruk sebanyak 35 orang $(62,5 \%)$ sehingga dapat disimpulkan teknologi yang tersedia ketika tidak mampu dikelola sehingga mengakibatkan kualitas tidur yang buruk yang dapat mengganggu kesehatan.

Kualitas Tidur yang buruk adalah keadaan dimana seseorang tidak menjaga keteraturan tidur, keteraturan tidur dan terjaga adalah sesuatu yang sangat penting, namun tak kalah penting dalam keteraturan itu adalah perlunya seseorang tidur awal dan bangun lebih awal. Hal yang penting bagi setiap orang untuk menjaga biologisnya agar tetap selaras sepenuhnya dengan rutinitas harian, dengan membatasi aktivitas yang membuat terjaga dimalam hari sehingga dapat membantu untuk efektifitas jam tidur karena kurang tidur dalam jangka waktu yang panjang dapat menyebabkan kerusakan otak, bahkan kematian. (Woods \& Scott 2016).

Berdasarkan hasil pendataan awal yang diperoleh di SMA Negeri 1 Langowan pada tanggal 18 Februari 2020 pada siswa kelas XI Matematika Ilmu pengetahuan Alam (MIA) di dapatkan hasil 6 kelas XI MIA yang ada. Dari hasil wawancara dengan 3 guru wali kelas dan 1 Guru Bimbingan Konseling (BK) dan data keterlambatan terbanyak ada di kelas XI MIA jika di bandingkan dengan kelas yang lain dengan presentase $42 \%$ untuk siswa kelas MIA, $38 \%$ untuk siswa kelas IIS, dan 20\% untuk kelas Bahasa. Faktanya setiap siswa yang terlambat saat ditanya alasan mereka jawabannya adalah terlambat bangun pagi dan alasan terlambat bangun pagi adalah karena bergadang untuk menjelajahi internet diberbagai media sosial pada saat malam hari dan data keterlambatan terbanyak yaitu pada kelas XI MIA. Sedangkan hasil wawancara pada 20 siswa dari kelas XI MIA 1 Sampai XI MIA 6, dari 20 siswa 17 diantaranya mengatakan waktu tidur mereka hanya 4-5 jam dalam sehari kemudian 3 siswa lainnya mengatakan waktu tidur mereka sekitar 6 jam/hari. Untuk alasan keterlambatan 13 siswa mengatakan terlambat dengan alasan menjelajahi media sosial pada malam hari dan 7 siswa lainnya memberikan alasan jarak rumah yang jauh dan susah mendapatkan kendaraan untuk pergi ke sekolah.

Fakta dilapangan yang di temui bahwa siswa yang menjelajahi media sosial hingga larut memiliki akun media sosial lebih dari dua dan dapat menghabiskan waktu hingga berjam-jam dan jam untuk tidur dibawah 7 jam perhari sehingga dari kebiasaan tersebut membuat kebutuhan istirahat dan tidur menjadi terganggu atau buruk dan terlambat bangun pagi menjadi alasan yang paling sering di temui. Berdasarkan fenomena-fenomena dan berbagai penelitian terkait yang telah dipaparkan diatas, penulis memandang penting untuk melakukan penelitian lebih dalam sehingga tujuan yang akan dicapai dalam penelitian ini ialah diketahui adanya hubungan antara penggunaan media sosial dengan kualitas tidur pada remaja dikelas XI Matematika Ilmu Alam (MIA) SMA N 1 Langowan.

\section{METODE PENELITIAN}

Penelitian ini termasuk dalam jenis penelitian kuantitatif dengan menganalisis gambaran hubungan antara kedua variabel yaitu variabel independen (Penggunaan Media Sosial) dan variabel dependen (Kualitas Tidur). Penelitian ini menggunakan desai penelitian cross sectional. Penelitian ini dilaksanakan secara online pada siswa SMA $\mathrm{N} 1$ Langowan pada tanggal 25-26 april 2020. Populasi penelitian ini merupakan seluruh Siswa kelas XI Matematika Ilmu Alam (MIA) berjumlah 181. Pengambilan sampel menggunakan teknik non random sampling dengan metode purposive sampling dengan rumus slovin dengan mendapatkan jumlah minimal dari perhitungan yaitu 64 siswa dan yang masuk dalam sampel sesuai kriteria inklusi berjumlah 80 siswa. Instrumen penelitian yang digunakan untuk mengukur variabel Penggunaan Media Sosial menggunakan kuesioner, kuesioner ini terdiri dari 6 pertanyaan dalam bentuk 
skala guttman dengan parameter penilaian yaitu waktu penggunaan, responden dikatakan tinggi penggunaannya terhadap media sosial jika ia memilih jawaban setiap saat pada (No.2) dan di katakan rendah penggunaannya jika memilih jawaban selain setiap saat. Pengukuran Kualitas tidur menggunakan The Pittsburgh Sleep Quality Index (PSQI) dengan mengkaji 7 komponen dalam kualitas tidur, yaitu Latensi tidur (No.2), Durasi tidur (No. 1\&3), Kualitas tidur (No.9), Efisiensi kebiasaan tidur (No.4), gangguan tidur (No.5), penggunaan obat tidur (No.6), dan gangguan fungsi tubuh di siang hari (No.7\&8), penilaian kuesioner ini yaitu skor dijumlahkan dan jika total nilai $\leq 5$ berarti kualitas tidur baik dan jika totalnya >5 menunjukkan bahwa kualitas tidur buruk.

Pengolahan data yang diperoleh dari hasil penelitian ini diolah secara manual dan dianalisis secara statistik melalui komuterisasi dengan beberapa tahap yaitu selecting, editing, coding, cleaning, tabulating dan entry (Notoadmodjo, 2012). Analisa Univariat bertujuan untuk menjelaskan atau mendeskripsikan karakteristik setiap variabel penelitian, untuk data Numerik (Umur) dan Kategorik (Jenis Kelamin) sedangkan Analisa bivariat adalah analisis yang dilakukan terhadap dua variabel yang diduga saling berhubungan atau berkolerasi (Notoatmodjo, 2012). Analisis Bivariat dilakukan untuk membuktikan hipotesa penelitian yaitu adakah hubungan antara penggunaan media sosial dengan kualitas tidur remaja di kelas XI Matematika Ilmu Alam (MIA) SMA N 1 Langowan, peneliti menggunakan uji Fisher Exact. Uji Fisher Exact digunakan untuk menguji keterkaitan antara dua variabel kategorik dimana ada sel yang memiliki nilai harapan kurang dari 5 , dengan kata lain data yang terlibat dalam uji Fisher Exact sedikit. Dengan nilai $\alpha=$ 0,05 . Bila nilai $\mathrm{p} \leq$ nilai $\alpha$, maka keputusannya adalah Ho ditoloak dan $\mathrm{Ha}$ diterima.

\section{HASIL dan PEMBAHASAN}

A. HASIL

1. Karakteristik Responden

Tabel 1. Distribusi Frekuensi Responden Menurut Umur.

\begin{tabular}{ccc}
\hline Umur & $\mathbf{n}$ & $\mathbf{\%}$ \\
\hline 15 & 11 & 13,75 \\
16 & 65 & 81,25 \\
17 & 4 & 5 \\
\hline Total & $\mathbf{8 0}$ & $\mathbf{1 0 0}$ \\
\hline Sumber : Data Primer, 2020 &
\end{tabular}

Tabel 2. Distribusi Frekuensi Responden Menurut Jenis Kelamin

\begin{tabular}{ccc}
\hline Jenis Kelamin & n & \% \\
\hline Perempuan & 53 & 66,25 \\
Laki-laki & 27 & 33,75 \\
\hline Total & $\mathbf{8 0}$ & $\mathbf{1 0 0}$ \\
\hline Sumber : Data Primer, 2020 & &
\end{tabular}

Tabel 3. Distribusi Frekuensi Responden menurut jenis-jenis Media Sosial yang digunakan.

\begin{tabular}{ccc}
\hline Jenis Media Sosial & $\mathrm{n}$ & $\%$ \\
\hline Instagram & 76 & 95 \\
Twitter & 19 & 23,75 \\
Youtube & 80 & 100 \\
Facebook & 78 & 97,5 \\
Zoom/Ruang & 53 & 66,25 \\
Guru/Google Meet & & \\
Whatsapp & 80 & 100 \\
\hline Sumber : Data Primer, 2020 & &
\end{tabular}

\section{Analisa Univariat}

a. Penggunaan Media Sosial

Tabel 4. Distribusi Frekuensi Responden Berdasarkan Waktu Penggunaan Media Sosial.

\begin{tabular}{ccc}
\hline $\begin{array}{c}\text { Waktu } \\
\text { Penggunaan }\end{array}$ & $\mathbf{n}$ & $\mathbf{\%}$ \\
\hline Tinggi & 67 & 83,75 \\
Rendah & 13 & 16,25 \\
\hline Total & $\mathbf{8 0}$ & $\mathbf{1 0 0}$ \\
\hline Sumber : Data Primer, 2020 & &
\end{tabular}


b. Kualitas Tidur

Tabel 5. Distribusi Frekuensi Menurut Kualitas Tidur.

\begin{tabular}{ccc}
\hline Kualitas Tidur & $\mathrm{n}$ & $\%$ \\
\hline Buruk & 58 & 72,5 \\
Baik & 22 & 27,5 \\
\hline Total & $\mathbf{8 0}$ & $\mathbf{1 0 0}$ \\
\hline
\end{tabular}

Sumber : Data Primer, 2020

\section{Analisa Bivariat}

Tabel 6. Hubungan Penggunaan Media Sosial dengan Kualitas Tidur remaja dikelas XI Matematika Ilmu Alam (MIA) SMA N 1 Langowan.

\begin{tabular}{crrrrrrrr}
\hline \multicolumn{1}{c}{ Kualitas Tidur } \\
\hline $\begin{array}{c}\text { Waktu } \\
\text { Penggunaan } \\
\text { Media Sosial }\end{array}$ & $\mathrm{n}$ & $\%$ & $\mathrm{n}$ & $\%$ & $\mathrm{n}$ & $\%$ & \\
Rendah & 13 & 100 & 0 & 100 & 13 & 100 & \\
Tinggi & 9 & 13,4 & 58 & 86,6 & 67 & 100 & $\mathbf{0 , 0 0 0}$ \\
\hline Total & $\mathbf{2 2}$ & $\mathbf{2 7 , 5}$ & $\mathbf{5 8}$ & $\mathbf{7 2 , 5}$ & $\mathbf{8 0}$ & $\mathbf{1 0 0}$ & \\
& & & & & & & &
\end{tabular}

Sumber : Data Primer, 2020

\section{B. PEMBAHASAN}

Penelitian ini dilakukan di SMA N 1 Langowan pada 80 siswa yang menjadi responden. Penelitian ini dilaksanakan pada tanggal 25-26 April 2020 yang bertujuan untuk mengetahui hubungan penggunaan media sosial dengan kualitas tidur pada remaja di kelas XI Matematika Ilmu Alam (MIA) SMA N 1 Langowan.

\section{Karakteristik Responden}

a. Berdasarkan Umur

Dari 80 responden yang diteliti diperoleh data menunjukkan bahwa semua responden adalah remaja yang berumur 1517 tahun. Berdasarkan hal tersebut dapat dikatakan bahwa pada usia tersebut remaja berada pada masa yang rentan dimana mereka lebih senang melakukan aktivitas yang dapat memberi mereka kesenangan secara pribadi (Young, 2009). Hal ini sejalan dengan survey nasional yang digelar Pew Internet \& American Life Project pada 17 juta remaja berumur 12 sampai dengan 17 tahun di amerika menyatakan bahwa 94\% remaja amerika melakukan aktivitas online dimedia sosial untuk mencari sumber atau bahan untuk menyelesaikan penelitian sekolah (Qomariyah, 2009).

b. Berdasarkan Jenis Kelamin

Dari keseluruhan responden yaitu 80 responden yang di teliti, jumlah terbanyak penggunaan media sosial adalah perempuan dengan total 53 siswa $(66,25 \%)$. Hal ini dikarenakan perempuan ternyata lebih aktif menggunakan media sosial dari pada laki-laki. Dalam waktu yang bersamaan mereka juga dapat menulis blog, bahkan waktu penggunaanupdate status di twitter dan facebook (Arif, 2013). Hasil penelitian Finances Online menemukan bahwa perempuan lebih tertarik untuk berinteraksi melalui media sosial di banding pria (Telekomunitas, 2013). Remaja perempuan lebih cenderung menggemari interaksi melalui media sosial dikarenakan remaja perempuan lebih memiliki keinginan untuk berbagi/bercerita dengan orang lain, hal ini yang menyebabkan remaja perempuan lebih dominan menggunakan media sosial di bandingkan dengan remaja laki-laki. Remaja perempuan cenderung memiliki tingkat keakraban yang dalam dengan orang-orang sekitarnya (Syamsoedin, 2015).

c. Berdasarkan Jenis-jenis Media Sosial yang digunakan

Berdasarkan Jenis-jenis media sosial yang dimiliki hasil hasil penelitian pada 80 responden di dapatkan hasil bahwa penggunaan youtube dan whatsapp adalah pemngguna terbanyak dengan presentase (100\%) di bandingkan dengan Twitter 19 pengguna $(23,75 \%)$, facebook 78 pengguna (97,5\%), Zoom/Ruang Guru/Google Meet 53 pengguna $(66,25 \%)$. Untuk pengguna Youtube di indonesia menurut KataData (2019) mencapai $88 \%$ dari total penduduk indonesia menggunakan youtube. Menurut penelitian yang di lakukan oleh Iksanti (2018) tentang penggunaan youtube menunjukan bahwa alasan remaja menggunakan youtube yaitu untuk mencari hiburan yang berkaitan dengan video blog yang berisi hal-hal yang bermanfaat seperti 
tutorial, humor, kegiatan keseharian vlogger yang dapat membuat subjek merasa tenang, bahagia, senang, terharu, nyaman, tentram, hal tersebut menunjukkan perasaan ke arah positif. Untuk pengguna Whatsapp mencapai $83 \%$ dari total penduduk indonesia menurut KataData (2019). Sejalan dengan penelitian yang dilakukan oleh Pangestika (2018) Whatsapp di manfaatkan untuk menyebarkan informasi pembelajaran antara lain : Group chat, foto, Video, pesan suara, dan dokumen, sehingga siswa juga dipermudah dalam berinteraksi untuk menyelesaikan tugas dan juga mempermudah untuk berkomunikasi secara umum maupun personal. Menurut peneliti sendiri untuk Youtube dan Whatsapp adalah salah satu sarana media sosial dimana memiliki peran dan manfaat bagi masyarakat umum tak terkecuali remaja yang duduk dibangku sekolah. Bagi remaja sendiri Youtube dan Whatsapp dapat menjadi sarana untuk bersosialisasi dalam kepentingan akademik maupun non akademik, sehingga kedua media tersebut paling banyak dimiliki oleh kalangan remaja.

\section{Hubungan penggunaan media sosial dengan kualitas tidurRemaja}

Berdasarkan Waktu Penggunaan Media sosial, Dari keseluruhan responden yaitu 80 responden yang diteliti hasil yang di dapatkan adalah waktu penggunaan media sosial dalam kategori tinggi berjumlah 67 siswa $(83,75 \%)$ dan untuk waktu pengunaan media sosial dalam kategori tinggi berjumlah 13 siswa $(16,25 \%)$. Penggunaan media sosial dibagi dua tipe pengguna yaitu aktif dan pengguna pasif. Menurut Woods \& Scott (2016) menjelaskan pengguna media sosial dapat dibedakan berdasarkan seberapa aktif atau pasif pengguna dalam menggunakan media sosial. Pengguna aktif ataupun pasif dibedakan berdasarkan bagaimana pengguna menggunakan media sosial tersebut dalam hal ini pengguna Aktif dalam kategori penggunaan yang tinggi dan pengguna pasif dalam kategori yang rendah. Hal ini sejalan dengan hasil penelitian yang dilakukan oleh Nurniati (2018) bahwa penggunaan media sosial yang aktif berjumlah 93 siswa $(66,9 \%)$ dimana dalam menggunakan media sosial siswa menggunakan berbagai fungsi dari media sosial tersebut seperti melihat gambar, berbagi pemikiran atau pengalaman, meng-klik link atau simbol tertentu sebagai bentuk feedback ataupun hanya sekedar menjelajahi konten halaman media sosial tersebut. Menurut peneliti penyebab dari tingginya penggunaan media sosial tersebut karena remaja harus menyesuaikan waktu mereka antara penggunaan media sosial untuk sekedar hiburan dan aktivitas belajar mengajar yang saat ini harus menggunakan media sosial sebagai media belajar dan juga media untuk bersosialisasi.

Berdasarkan hasil penelitian yang dilakukan pada 80 responden menunjukkan jumlah responden yang mengalami kualitas tidur yang buruk berjumlah 58 siswa $(72,5 \%)$, sedangkan untuk kualitas tidur yang baik berjumlah 22 siswa $(27,5 \%)$. Ulumudin (2011) manusia mempunyai kebutuhan tertentu yang harus dipenuhi secara memuaskan melalui proses homeostasis, baik fisiologis maupun psikologis. Seseorang memiliki beberapa kebutuhan yang belum terpenuhi akan lebih dulu memenuhi kebutuhan fisiologisnya dibandingkan kebutuhan orang lain. Kebutuhan fisiologis tersebut salah satunya adalah istirahat dan tidur. Hal yang mempengaruhi kualitas tidur menurut penelitian yang dilakukan oleh Case Western Reserve School of Medicine (2008) yaitu internet, karena pada saat ini penggunaan media elektronik dan akses internet serta jejaring sosial/media sosial bukan lagi hal baru, remaja banyak menghabiskan waktunya untuk beraktivitas di media sosial sehingga membuat waktu untuk tidur berkurang, yang seharusnya waktu tidur 8 jam menjadi 4 atau 5 jam 
perhari karena menggunakan media sosial yang berlebihan, kemudian penggunaan internet sendiri juga layanan yang di sediakan dapat membantu dalam bidang akademik. Menurut peneliti sendiri terkait dengan remaja yang mengalami kualitas tidur yang buruk karena mereka mengerjakan tugas pada malam hari, chatting dengan teman pada malam hari, browsing dan downloading hal-hal yang berkaitan dengan hobi dan streaming film ataupun vlog untuk hiburan pada malam hari.

Dalam penelitian ini ditemukan adanya hubungan antara penggunaan media sosial dengan kualitas tidur pada remaja, dapat dilihat melalui Uji Fisher's exact test didapat koefisien korelasi bernilai negatif dengan tingkat signifikan pValue adalah sebesar 0,000 (tabel 5.6, artinya terdapat hubungan yang signifikan antara penggunaan media sosial dengan kualitas tidur pada remaja di kelas XI Matematika Ilmu Alam (MIA) SMA N 1 langowan.

Hal ini membuktikan dengan hasil dari total 80 responden 67 responden menggunakan media sosial dalam kategori tinggi dan 58 dari 80 responden mengalami kualitas tidur yang buruk. Dari data yang didapatkan bahwa penggunaan media sosial yang tinggi dapat menyebabkan kualitas tidur buruk bagi remaja kemudian sebaliknya, responden yang rendah penggunaan media sosialnya dan memiliki kualitas tidur yang baik kurang dari setengah. Dari hasil penelitian dapat dilihat bahwa penggunaan media sosial memiliki hubungan dengan kualitas tidur pada remaja.

Hasil pengisian kuesioner menunjukkan bahwa sebagian besar remaja di kelas XI Matematika Ilmu Alam (MIA) SMA N 1 Langowan menggunakan media sosial dalam kategori tinggi, selain itu sebagian besar juga mengalami kualitas tidur yang buruk akibat penggunaan media sosial yang tinggi. Responden yang mengalami kualitas tidur buruk karena penggunaan media sosial yang tinggi adalah responden dengan rentang umur 16 tahun yang dominannya berjenis kelamin perempuan.

Berdasarkan hasil yang ada juga remaja di kelas XI Matematika Ilmu Alam (MIA) SMA N 1 Langowan menggunakan media sosial dalam situasi apapun, pada saat jatwal pelajaran dipadatkan pada pagi hingga siang hari membuat responden memanfaatkan waktu untuk istirahat dengan menggunakan media sosial walaupun hanya sekedar istirahat untuk makan siang dan juga pada malam hari, banyak waktu yang digunakan oleh responden untuk menggunakan media sosial hingga melupakan waktu untuk istirahat dan jam untuk tidur tidak digunakan sebagaimana mestinya.

Penggunaan media sosial yang tinggi pada remaja secara langsung mengakibatkan kualitas tidur yang buruk (Xanidis \& Brignell, 2016). Kualitas tidur adalah kemampuan individu untuk tetap tidur dan mendapatkan jumlah tidur yang baik yaitu tidur tenang, segar saat bangun di pagi hari dan semangat melakukan aktivitas. Kualitas tidur mempengaruhi kehatan dan kualitas hidup secara keseluruhan (Syamsoedin, 2015).

Hasil ini sejalan dengan penelitian Woods \& Scott (2016) yang menyatakan bahwa penggunaan media sosial sangat dikaitkan dengan kualitas tidur yang buruk. Kontribusi baru dari penelitian ini adalah temuan bahwa penggunaan media sosial malam hari lebih kuat berhubungan dengan tidur yang buruk. Penggunaan media sosial disaat akan tidur akan mengganggu produksi melatonin melalui paparan layar digital pada waktu tidur, selain itu peringatan media sosial dapat mengganggu proses tidur remaja.

Penelitian dari Levenson, J.C. et al. (2016) memiliki persamaan membahas penggunaan media sosial dengan tidur, perbedaannya, penelitian ini lebih menjelaskan bagaimana media sosial dapat menyebabkan munculnya gangguan tidur. Mereka mengungkapkan beberapa 
kemungkinan prinsip yang mendasari hubungan antara penggunaan media sosial dan gangguan tidur. Pertama, penggunaan media sosial akan menggantikan tidur, misalnya seorang tetap berkutat dengan Instagram, dengan begitu waktu tidur akan berkurang. Kedua, pengunaan media sosial dapat meningkatkan gairah emosional, kognitif dan fisiologis. Ketiga, cahaya terang yang di pancarkan oleh perangkat media sosial dapat menunda ritme sirkadian.

Sejalan dengan suatu penelitian yang menyebutkan bahwa remaja yang kecanduan smartphone cenderung menghabiskan lebih banyak waktu di smartphone mereka, namun mungkin tidak dapat menggunakan smartphone secara intensif disiang hari karena kegiatan akademis dan larangan dari sekolah, sehingga remaja akan intensif menggunakan smartphone di malam hari yang akan mengurangi waktu tidur. Elektromagnetik yang dipancarkan oleh smartphone mempengaruhi aliran darah serebral dan melatonin dimana merupakan suatu hormon penting meningkatkan kualitas tidur (Liu et al. 2017).

Beberapa responden menggunakan media sosial dengan tinggi namun memiliki kualitas tidur yang baik, hal ini disebabkan karena mereka mampu mengatur waktu kapan menggunakan media sosial dan kapan untuk tidur sehingga mereka tidur pada waktunya. Kualitas tidur buruk yang dialami oleh penggunaan media sosial yang rendah, karena adanya faktor lain yang menyebabkan kualitas tidur buruk, seperti kegiatan dan tugas sekolah.

Fitur-fitur baru dari media sosial mampu menarik perhatian semua kalangan, tidak terkecuali remaja. Mulai dari instagram, twitter, youtube, facebook, zoom/ruang guru/google meet, dan whatsapp adalah sebagian dari media sosial yang hampir dimiliki oleh semua responden. Akses yang luas tanpa batas didukung dengan kepemilikan kuota sendiri menjadikan penggunanya menikmati tanpa menghiraukan aktivitas lain sehingga kualitas tidur yang dikorbankan sebagian besar dari mereka.

Potter \& Perry (2010) menjelaskan ada beberapa faktor yang mempengaruhi tidur, salah satunya adalah gaya hidup. Gaya hidup remaja saat ini yang tidak dapat terpisahkan dari smartphone menyebabkan mereka menggunakan media sosial setiap saat, sesuai dengan kuesioner media sosial yang menunjukkan hampir seluruh responden mengatakan menggunakan media sosial setiap saat. Proses tidur menjadi terganggu akibat remaja yang fokus memainkan media sosial hingga larut malam dan masih menghiraukan peringatan dari media sosial ketika remaja memulai untuk tidur. Pertanyaan tersebut didukung dengan hasil kuesioner PSQI yang telah di isi, bahwa nilai tinggi dan yang banyak dialami responden adalah poin latensi dan durasi tidur. Latensi merupakan durasi dari berangkat tidur hingga tertidur, sedangkan durasi adalah waktu mulai tertidur hingga bangun dipagi hari.

Menurut peneliti kualitas tidur yang buruk akibat dari penggunaan media sosial yang tinggi dapat berdampak buruk bagi kesehatan fisik dan psikologis, Kualitas tidur yang buruk yang berdampak pada segi fisik khususnya pada remaja yang masih duduk dibangku sekolah yaitu seperti mudah mengantuk pada siang hari karena kurang tidur pada malam hari yang menyebabkan menurunnya konsentrasi belajar sehingga berdampak buruk bagi prestasi akademik remaja tersebut di sekolah, kemudian untuk dampak pada psikologis yaitu pada perubahan emosi (mood) juga menurunkan semangat dalam aktivitas sehari-hari. Menurut peneliti sendiri ada beberapa faktor yang dapat mempengaruhi hasil dari penelitian ini yaitu kurangnya pemahaman responden tentang penggunaan media sosial dan kualitas tidur, misalnya pada penggunaan media sosial apakah penggunaannya terlalu sering menggunakan media sosial ataupun sebaliknya, kemudian untuk kualitas tidur, yang dapat mengakibatkan kualitas tidur buruk pada responden bisa saja bukan 
hanya penggunaan media sosial tapi penggunaan obat tidur dan juga kenyamanan saat akan tidur, tetapi peneliti dalam penelitian ini telah membuat panduan yang menjelaskan cara mengisian, serta kuesioner yang digunakan sangat jelas pertanyaannya sehingga mudah dimengerti dan di pahami dalam pengisian kuesioner tersebut.

Oleh karena peneliti menyimpulkan bahwa ketidakmampuan remaja dalam memenejemen waktu penggunaan media sosial dengan baik dan benar ketika berada di sekolah ataupun berada dirumah, akan berdampak pada ketidakaturan pola istirahat dan tidur pada remaja sehingga kualitas tidur pada remaja menjadi buruk. Hal ini dikarenakan tidak terpenuhinya pola tidur ideal bagi remaja yaitu 8-10 jam semalam apalagi saat siswa mengikuti pembelajaran jarak jauh atau PJJ, sehingga rendahnya waktu bagi remaja untuk memenuhi kebutuhan istirahat dan tidur, akan menyebabkan kualitas tidur remaja menjadi buruk sehingga membuat semakin tinggi dampak negatif dari penggunaan media sosial tersebut.

\section{KESIMPULAN}

Responden menunjukkan gambaran penggunaan media sosial dalam kategori Tinggi dan gambaran kualitas tidur dalam kategori buruk. Terdapat hubungan antara penggunaan media sosial dengan kualitas tidur pada remaja di kelas XI Matematika Ilmu Alam (MIA) SMA N 1 Langowan, maka dari itu semakin tinggi waktu penggunaan media sosial maka semakin buruk kualitas tidur yang akan di alami.

\section{DAFTAR PUSTAKA}

Arif. (2013). Perempuan ternyata lebih aktif di internet dibanding pria. Diakses : 4 Mei 2020 https://www.merdeka.com/teknologi/p erempuan-ternyata-lebih-aktif-diinternet-dibanding-pria.html
Armaya, J. (2017). Hubungan penggunaan gadget dengan kualitas tidur pada remaja di SMP Negeri 1 Banda Aceh. Diakses 13 Februari 2020 : http://jim.unsyiah.ac.id/FKep/article/d ownload/3872/2942.

Asosiasi Penyelenggara Jasa Internet Indonesia (APJII). (2018). Penetrasi \& profil perilaku pengguna internet Indonesia survei 2018. Diakses : pada 18 februari 2020 https://apjii.or.id/survei2018/downloa d/94IpUV5Kjaqnt3GdHWFwMvOE6 $\underline{\text { hZiuJ }}$

Case Western Reserve School of Medicine. (2008). Poor Teen Sleep Habits may raise Blood Pressure. Diakses pada 3 Mei 2020 : https://www.cleveland.com/health/20 $\underline{\text { 08/08/cleveland_study_says_sleepstar }}$ .html

Iksanti. (2018). Sikap Remaja Terhadap Tayangan Vlog. Diakses : 4 Mei 2020 http://eprints.ums.ac.id/66375/11/NA SKAH\%20PUBLIKASI-27.pdf

KataData. (2019). Profil Pengguna Medsos Indonesia. Diakses : 4 Mei 2020

https://katadata.co.id/infografik/2019/ 03/06/youtube-medsos-no-1-diindonesia\#

Liu, Q. et al., (2017). Computers In human behavior mobile phone addiction and sleep quality among chinese adolescents : A moderated mediation model. Computers in human behavior, 72, pp.108-114. Available at : http://dx.doi.org/10.1016/j.chb.2017.0 2.042 .

Notoatmodjo, S. (2012). Metodologi penelitian kesehatan. Jakarta : PT. Rineka Cipta

Nurniati, N. (2018). Hubungan durasi penggunaan media sosial dengan kualitas tidur pada remaja kelas VIII di SMP Muhammadiyah 1 Yogyakarta. Diakses : 13 Februari 2020 
http://digilib.unisayogya.ac.id/4392/1/ naspub\%20fix.pdf-min.pdf.

Pangestika. (2018). Pengaruh pemanfaatan media sosial whatssapp terhadap penyebaran informasi pembelajaran di SMA negeri 5 Depok. Diakses : http://repository.uinjkt.ac.id/dspace/bi tstream/123456789/41759/1/NUR\%2 0LIA\%20PANGESTIKA-FITK.pdf

Potter, P.A. \& Perry, A.G. (2010). Fundamental keperawatan 7th ed., Jakarta: Salemba Medika.

Qomariah, Astutik. (2009). Perilaku penggunaan internet pada kalangan remaja di perkotaan. Di akses : 4 Mei 2020http://repository.unair.ac.id/1824 $\underline{1 /}$

Riyadi, S. \& Widuri, H. (2015). Kebutuhan dasar manusia aktivitas istirahat diagnosis nanda. Yogyakarta: Gosyen Publishing.

Sudiyatmoko, R. (2015). Panduan optimalisasi media sosial untuk kementrian perdagangan RI.

Syamsoedin, W.K.., Bidjuni, H. \& Wowiling, F. (2015). Hubungan durasi penggunaan media sosial dengan kejadian insomnia pada remaja di SMANegeri 9 Manado. ejournal keperawatan, 3(1). Diakses : $21 \quad$ Februari 2020 https://ejournal.unsrat.ac.id/index.php /jkp/article/view/6691/6211

Ulumudin, Bahrul. (2011). Hubungan tingkat stress dengan kejadian insomnia pada mahasiswa program studi ilmu keperawatan universitas diponegoro. Diakses 4 Mei 2020 https://id.scrib.com/doc/188228462/ar tikel-hubungan-tingkat-stres-dengankejadian-insomnia

Websindo. (2019). Indonesia digital 2019 : media social. Diakses : 13 Februari $2020 \mathrm{https}: / /$ websindo.com/indonesiadigital-2019-media-sosial/
Woods, H. C., \& Scott, H. (2016). \#Sleepyteens: Social media use in adolescence is associated with poor sleep quality, anxiety, depression and low self-esteem. Journal of Adolescence, 51, 41-49. doi:10.1016/j.adolescence.2016.05.00 8.

Xanidis, N. \& Brignell, C.M., (2016). The association between the use of social network sites, sleep quality and cognitive function during the day. Computers in human behavior, 55, pp.121-126. Available at : http://dx.doi.org/10.1016/j.chb.2015.0 $\underline{9.004}$.

Young, K. (2009). Understanding Online Gaming Addiction and Treatment Issues for adolescents. The American Journal of Family Therapy, 37(5), 355-372. doi: 10.1080/01926180902942191. Diakses pada 30 Mei 2020 